Original Article

\title{
POTENTIAL OF CELLULASE OF CHAETOMIUM GLOBOSUM FOR PREPARATION AND CHARACTERIZATION OF MICROCRYSTALLINE CELLULOSE FROM WATER HYACINTH (EICHHORNIA CRASSIPES)
}

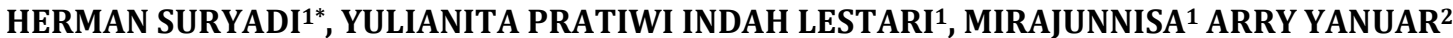

${ }^{1}$ Laboratory of Microbiology and Biotechnology, Faculty of Pharmacy, Universitas Indonesia, Pondok Cina, Depok, 16424, West Java, Indonesia, ${ }^{2}$ Laboratory of Biomedical Computation, Faculty of Pharmacy, Universitas Indonesia, Pondok Cina, Depok 16424, West Java, Indonesia

Email: hsuryadi@farmasi.ui.ac.id

Received: 30 Nov 2018, Revised and Accepted: 26 Apr 2019

\begin{abstract}
Objective: This study aimed to increase the yield of microcrystalline cellulose (MCC) made from water hyacinth a-cellulose by enzymatic hydrolysis by using purified enzyme and to find it's characteristics compared to the reference.

Methods: In this research, MCC was prepared from water hyacinth powder through the chemical isolation process of a-cellulose, followed by enzymatic hydrolysis with purified cellulase from Chaetomium globosum. The yield of MCC was improved by using purified enzyme and optimization of temperature, $\mathrm{pH}$, and hydrolysis time. Identification was carried out by using ZnCl and infrared spectrophotometry, followed by characterization of MCC include particle size analysis (PSA) and diffractogram pattern (X-Ray Diffraction) compared to reference Avicel PH 101.

Results: Purified enzyme from Chaetomium globosum has high activity with a clear zone area of $45 \mathrm{~mm}$ with cellulolytic index 6.5 that almost same as Trichoderma reesei $\left(50 \mathrm{~mm}\right.$ ), with the cellulase enzyme activity of $6.691 \mathrm{U} / \mathrm{ml}$. The optimum condition was at a temperature of $50^{\circ} \mathrm{C}$ and pH 6.0 with the hydrolysis time of $2 \mathrm{~h}$, which produced 95\% yield of MCC. Identification with ZnCl and FTIR spectrum showed positive results, similar to the reference. The results of organoleptic test, particle size analysis, and diffractogram pattern (X-Ray Diffraction) showed crystalline characteristic similar to reference (Avicel PH 101).
\end{abstract}

Conclusion: Enzyme from Chaetomium globosum has a higher activity of cellulase than Trichoderma reesei with MCC obtained was 95\%. Based on the comparison of the organoleptic test, particle size analysis, and diffractogram pattern, MCC from water hyacinth has a great potential which showed similar characteristic to reference (Avicel pH 101).

Keywords: Microcrystalline cellulose, Water hyacinth, Enzymatic hydrolysis, Enzyme purification, Enzyme characterization, MCC characterization

(C) 2019 The Authors. Published by Innovare Academic Sciences Pvt Ltd. This is an open-access article under the CC BY license (http://creativecommons.org/licenses/by/4.0/) DOI: http://dx.doi.org/10.22159/ijap.2019v11i4.31081

\section{INTRODUCTION}

Water hyacinth (Eichhornia crassipes) is a weed plant in water areas that live floating on deep water. Water hyacinth has high growth speed, because of it's rapid growth, the water hyacinth can cover the surface of the water and cause problems in the environment, so this plant is considered a weed that can damage the aquatic environment. Water hyacinth was known to have high cellulose content, namely $60 \%$ cellulose, $8 \%$ hemicellulose, and $17 \%$ lignin [1]. Cellulose that produced from water hyacinth has the potential for the manufacture of MCC [2].

MCC is an additional material that was taken into account in the pharmaceutical, food, cosmetics, and other industries. MCC is one of the most important tablet excipients because of the binding properties of tablets in the direct compression tablet creation method[3]. MCC can be synthesized by different processes such as acid hydrolysis and enzymatic hydrolysis. The enzymatic hydrolysis process is more interesting when viewed from energy use because it can be carried out at low temperatures, while chemical hydrolysis requires high temperatures and uses chemicals that can pollute the environment, but enzymatic hydrolysis takes longer [4].

Cellulose is commonly degraded by an enzyme called cellulase [5] Cellulases (1,4)-(1,3:1,4)-/J-D-glucan 4-glucanohydrolase (EC 3.2.1.4) or the enzyme essential for the Carbon cycle in nature. These cellulases are commercially used in the food industry for clarification of fruits and juices and pharmaceuticals industry. It is almost necessary to purity with $100 \%$ purity and yield $[6,7]$. Cellulase enzymes are usually produced by microbes, for example, fungi, bacteria and also protozoa besides that also produced by plants and animals [8]. Fungi are known to actively decompose cellulose in nature by producing extracellular cellulase enzymes. The fungus of the genus Aspergillus, Bulgaria, Chaetomium, Cladosporium, Coriolus, Fusarium, Geotcrichum, Helotium,
Myrothecium, Paecilomyes, Penicillium, Phanaerochaete, Poria, Schizophyllium, Serpula, and Trichoderma are known to have the ability to decompose wood $[9,10]$.

This paper reports the preparation of MCC from water hyacinth powder using an enzymatic method which used an enzyme derived from the mold which was compared with Avicel PH 101. Preparation of MCC from water hyacinth powder by enzymatic reaction has already performed by Suryadi et al. [11]. In our previous study, the enzyme that used was still in the form of crude enzymes while in this study using the purified enzyme. Beside that, in previous studies used local isolates and Trichoderma reesei while in this study using Chaetomium globosum. So, that it can be used as new knowledge about other types of mold that can produce cellulase enzymes. Identification MCC was carried out by $\mathrm{ZnCl}$ and infrared spectrophotometry, followed by characterizations of microcrystalline cellulose compared to the reference, Avicel PH 101.

\section{MATERIALS AND METHODS}

\section{Instruments}

The instruments analysis used were autoclave (Hirayama), incubator (Memmert), oven (WTB Binder), analytical balance (Acculab), particle size analyzer (Cilas 1190), water bath shaker, hotplate stirrer (Corning), pH meter (Eutech), centrifugator (Kubota 6800), UV-Vis spectrophotometer (Shimadzu), pH meter, and X-ray diffractogram (Rigaku), vacuum oven (Hotpack), blender (Maspion), sieve, filter paper, ose, tweezer, column, pipette volume and other glass wares commonly used in laboratories.

\section{Raw material}

Water hyacinth (Eichhornia crassipes) that used in this study were obtained from Balai Penelitian Tanaman Rempah dan Obat (Balitro), 
Cimanggu, Ciwaringin district, Central Bogor West Java, Indonesia, $16124\left(6.5810^{\circ} \mathrm{S}, 106.7898^{\circ} \mathrm{E}\right)$.

The mold used in this study was Chaetomium globosum and Paecilomyes niveus obtained from IPB Culture Collection (IPB CC), Department of Biology, Faculty of Mathematics and Natural Sciences, Bogor Agricultural University.

Trichoderma reesei from Universitas Indonesia Culture Collection (UICC), Department of Biology, Faculty of Mathematics and Natural Sciences, Universitas Indonesia.

\section{Chemical material}

The chemicals used in this study were Avicel PH 101 (aicma) as a comparison reference, sodium hydroxide (Merck), sodium hypochlorite (Merck), sodium nitrite (Merck), sodium sulfite (Merck), Potato Dextrose Agar/PDA (DifcoTM), Potato Dextrose Broth/PDB (Merck), yeast extract (Himedia), tween 80 (Merck), Peptone (DifcoTM), ammonium sulfate (Merck, Germany), Diethylaminoethyl (DEAE)-Cellulose resin, Glucose (Merck), dinitrosalicylic acid (Himedia), nitric acid (Merck), acetic acid (Merck), $\mathrm{KBr}$ powder (Merck), zinc chloride (Merck), potassium iodide (Bratachem), aquadestilata (Merck), aquabidestillata (Otsuka).

\section{Sterilization}

The tools to be used such as Petri dishes, round squash, test tubes, pipettes, paper discs, etc., and the medium to be used was sterilized using an autoclave at a temperature of $121^{\circ} \mathrm{C}$ for $15 \mathrm{~min}$.

\section{Maintenance of mold isolates}

Chaetomium globosum, Paecilomyes niveus, and Trichoderma reesei colonies were regenerated in PDA medium. Incubation was carried out at $27^{\circ} \mathrm{C}$ for $7 \mathrm{~d}$.

\section{Isolation of a-cellulose}

Every $150 \mathrm{~g}$ of water hyacinth powder was mixed with $3.5 \%$ nitric acid (containing $20 \mathrm{mg}$ of sodium nitrite) as much as $2 \mathrm{~L}$ in a container. The next procedure referred to our previous research [11].

\section{Extraction of cellulase enzyme}

Colonies of Chaetomium globosum are regenerated in PDA medium. Incubation was carried out at $27^{\circ} \mathrm{C}$ for $7 \mathrm{~d}$. The spore suspension was made by adding $10 \mathrm{ml}$ of aquabidestillata to a tube containing isolate culture in the agar medium. Shake the spores to mix with aquabidestillata. $5 \mathrm{ml}$ of spore suspension in $10 \mathrm{ml} 0.1 \%$ tween 80 was added with nutrient broth solution. Stir the mixture at $150 \mathrm{rpm}$ for $7 \mathrm{~d}$ in a shaker incubator. A mixture of $30 \mathrm{ml}$ of the solution was taken and centrifuged at $3000 \mathrm{rpm}$ for $10 \mathrm{~min}$ at $4^{\circ} \mathrm{C}$. Every $8 \mathrm{~h}, 2 \mathrm{ml}$ of the sample was taken and then centrifuged at $5000 \mathrm{rpm},{ }^{\circ} \mathrm{A}$ for $15 \mathrm{~min}$. Then, a crude enzyme extract was taken in the form of a supernatant, then continued with the purification of the enzyme[11].

\section{Purification of cellulase}

Cellulase was purified through precipitation ammonium sulfate [12], allowed by dialysis with selofan material [13], and finally by DEAE-C column chromatography [14].

\section{Characterization of cellulase}

Cellulase characterization was performed by optimization of $\mathrm{pH}$, temperature, and time of hydrolysis [12]. Each experiment was conducted thrice and the standard deviation for each experimental result was calculated using Microsoft Excel.

\section{Screening of transparent zone-based cellulose activity in medium CMC}

Cellulolytic microbial selection using CMC media on Petri dishes. Enzyme was dripped on disc paper by optimizing various volume variations. After incubating $24 \mathrm{~h}$ at room temperature, ditoian congo red solution $0.1 \%(\mathrm{~b} / \mathrm{v})$ and $1 \% \mathrm{NaCl}$ solution was added. Cellulolytic activity was determined by the cellulolytic index value which was the difference between the diameter of the clear zone and the diameter of the colony [15].
For comparison, Trichoderma reesei petri dish was also planted (molds that are often used in research for cellulase enzyme extraction). Furthermore, the cellulolytic index can be calculated:

$$
\text { Cellulolytic Index: } \frac{A-B}{B}
$$

Information: $\mathrm{A}=$ the diameter of the clear zone $(\mathrm{mm}) ; \mathrm{B}=$ the diameter of the colony $(\mathrm{mm})$.

\section{DNS method}

Cellulase activity was tested based on the method of Zhang et al. (2006) with Dinitro salicylic acid (DNS) reagent, with a slight modification, used $1 \%$ carboxymethyl-cellulose (CMC) as a substrate [12].

\section{Preparation and characterization of MCC by enzymatic hydrolysis}

As much as $10 \mathrm{~g}$ of a-cellulose water hyacinth were dissolved in the $100 \mathrm{ml}$ acetate buffer $(0.05 \mathrm{M}, \mathrm{pH} 4.8)$ while $3 \mathrm{ml}$ of cellulase enzyme was added and stirred slowly. This process is carried out twice, with crude enzyme and pure enzyme. The mixed solution was stirred at 150 $\mathrm{rpm}$ at $48^{\circ} \mathrm{C}$ for $72 \mathrm{~h}$ on water shaking incubator. The mixture was centrifuged at $10,000 \mathrm{rpm}$ (at $7-10^{\circ} \mathrm{C} 20 \mathrm{~min}$ ). The precipitated residue was washed with aqua destilata to remove the remaining enzymes on cellulose and then dried with an oven at $60{ }^{\circ} \mathrm{C}$ for 48 .

\section{Identification with $\mathrm{ZnCl}$}

Iodine zinc solution was prepared by dissolving $20 \mathrm{~g}$ of zinc chloride and $6.5 \mathrm{~g}$ of potassium iodide in $10.5 \mathrm{ml}$ of water. Add $0.5 \mathrm{~g}$ of iodine, and shake for $15 \mathrm{~min}$. Add about $10 \mathrm{mg}$ of MCC to the watch glass, and dissolve it in $2 \mathrm{ml}$ of zinc chloride solution [16]. The compound formed will be violet blue.

\section{FTIR}

$\mathrm{KBr}$ powder which has been dried at $105^{\circ} \mathrm{C}$ for $24 \mathrm{~h}$ was weighed carefully $\pm 99 \mathrm{mg}$ then added MCC $\pm 1 \mathrm{mg}$ powder. The mixture is crushed and mixed until homogeneous, then put into a disk or discshaped mold. Weigh carefully $100 \mathrm{mg} \mathrm{KBr}$ for blank and make a baseline. Perform scanning in $4000 \mathrm{~cm}^{-1}$ to $400 \mathrm{~cm}^{-1}$ wave number area [17]. The MCC FTIR spectrum made from water hyacinth pulp was then compared to the FTIR spectrum from reference raw materials (Avicel PH 101) using FTIR spectrophotometry.

\section{Organoleptic examination}

Characterization of forms, namely samples placed on a white base (parchment paper or the like), then observed the shape or appearance, color, taste, and smell [18].

\section{Size analysis and particle size distribution}

Particle size distribution was obtained by Particle Size Analyzer Mikro (CILAS1190 Liquid).

\section{$\mathrm{X}$-Ray diffraction analysis}

Crystal analysis was performed using X-ray diffraction (XRD) (Rigaku Miniflex 600) [11].

\section{RESULTS}

\section{Isolation of a-cellulose}
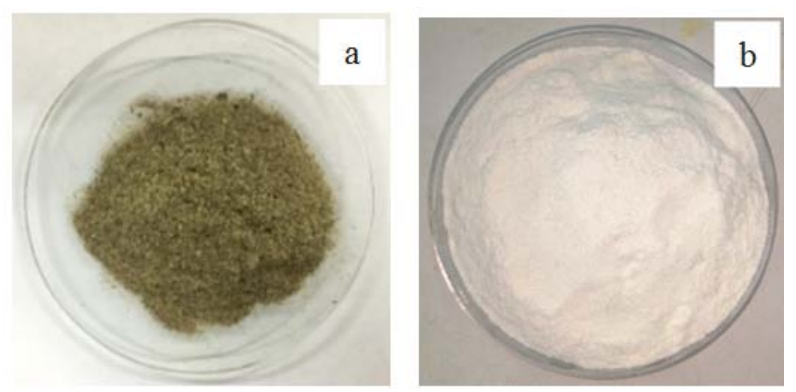

Fig. 1: Water hyacinth powder (a) and a-cellulose (b) 
The result of $\alpha$-cellulose isolation obtained from $150 \mathrm{~g}$ of water hyacinth powder was $21.8 \mathrm{~g}(14.53 \%)$.

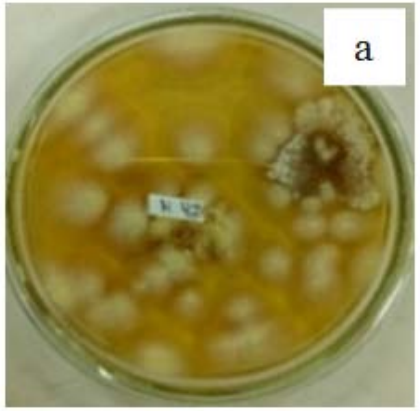

b

Fig. 2: Chaetomium globosum (a); crude enzyme after centrifugated (b)

\section{Extraction of cellulase enzyme}

Cellulase enzyme extraction was performed by dissolving $10 \mathrm{ml}$ of spore suspension and $10 \mathrm{ml}$ of $0.1 \%$ Tween 80 into the nutrient solution. The addition of tween $800.1 \%$ was done to increase the permeability of the cells so that the enzyme is easier to get out of the cell wall. From the centrifugation, results obtained a supernatant crude cellulase enzyme in which the pellets are formed like thin of the thread.

\section{Purification of cellulase}

All fractions obtained through multilevel (gradual) elution, after measuring the protein (using Bradford method) at a wavelength of $595 \mathrm{~nm}$ and select cellulase activity, it was obtained 7 protein fraction (P1, P2, P3, P4, P5, P6, and P7) as shown in fig. 3. The first fraction (P1) appears when elution of pure enzymes without the buffer. The second fraction (P2) appears when elution of the enzyme with a buffer. The third fraction (P3) appeared elution with stepwise $\mathrm{NaCl} 0.05 \mathrm{M}$. The fourth fraction (P4) appeared elution with stepwise $\mathrm{NaCl} 0.1 \mathrm{M}$. The fifth fraction (P5) appeared elution with stepwise $0.2 \mathrm{M} \mathrm{NaCl}$ sixth fraction (P6) appears because of washing the resin with $\mathrm{NaCl}$, the seventh fraction (P7) appears because of washing the resin with buffer. The results of enzyme activity can be seen in table 1.

Dialysis was used to eliminate the effect of ammonium sulfate salt in enzyme proteins. Dialysis was done to remove residual salt in the enzyme so that the cellulase enzyme obtained can proceed to the next purification step.

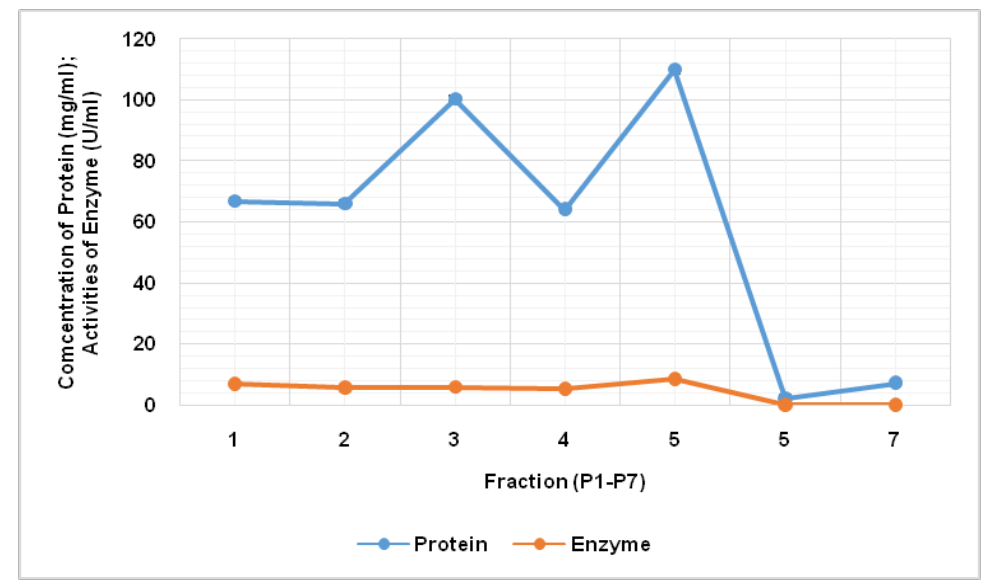

Fig. 3: Elution profile of DEAE-cellulose column chromatography for the purification of cellulose, all values are reported as mean \pm SD (Standard deviation), $\mathrm{n}=3$ measurements

All fractions were collected and from each of these protein peaks, specific activity was measured. the highest specific activity was found in the first fraction (P1), which amounted to $6691 \mathrm{mU} / \mathrm{mg}$ and a purity level of 2.15 times to the crude enzyme (table 1).

Table 1: Summary of the stages of enzyme purification

\begin{tabular}{|c|c|c|c|c|c|c|c|c|}
\hline Steps & $\begin{array}{l}\text { Volume } \\
(\mathrm{ml})\end{array}$ & $\begin{array}{l}\text { Protein } \\
(\mathrm{mg} / \mathrm{ml})\end{array}$ & $\begin{array}{l}\text { Total } \\
\text { protein (mg) }\end{array}$ & $\begin{array}{l}\text { CM case } \\
\text { activity }(\mathrm{mU} / \mathrm{ml})\end{array}$ & $\begin{array}{l}\text { Total cellulase } \\
\text { activity }(\mathrm{mU})\end{array}$ & $\begin{array}{l}\text { Specific activity } \\
\text { (mU/mg) }\end{array}$ & $\begin{array}{l}\text { Purification } \\
\text { fold }\end{array}$ & Yield (\%) \\
\hline \multirow[t]{2}{*}{$\mathrm{CE}$} & 400 & $109.04 \pm 0.03$ & 43616 & $5095 \pm 0.51$ & 2038000 & 46.73 & 0 & 100 \\
\hline & \multicolumn{8}{|c|}{ Fractionation with ammonium sulfate } \\
\hline F1 & 18.10 & $93.39 \pm 6.72$ & 1690.36 & $7670 \pm 0.11$ & 137680.73 & 81.45 & 1.74 & 6.76 \\
\hline F2 & $\begin{array}{l}379.90 \\
\text { Dialysis }\end{array}$ & $56.60 \pm 0.23$ & 21502.34 & ND & ND & ND & ND & ND \\
\hline \multirow[t]{2}{*}{ Dt } & 8 & $93.14 \pm 0.26$ & 745.12 & $8440 \pm 0.45$ & 67520 & 90.62 & 1.94 & 3.31 \\
\hline & \multicolumn{8}{|c|}{ Ion exchange chromatography (DEAE-Streamline) } \\
\hline P1 & 6 & $66.73 \pm 0.77$ & 400.38 & $6691 \pm 0.01$ & 40146 & 100.27 & 2.15 & 1.97 \\
\hline $\mathrm{P} 2$ & 6 & $67.50 \pm 2.66$ & 405 & $5740 \pm 0.04$ & 34440 & 85.04 & 1.82 & 1.69 \\
\hline P3 & 6 & $102.89 \pm 3.71$ & 617.34 & $5813 \pm 0.01$ & 34878 & 56.50 & 1.21 & 1.71 \\
\hline $\mathrm{P} 4$ & 6 & $62.50 \pm 2.66$ & 375 & $5162 \pm 0.01$ & 31020 & 82.72 & 1.77 & 1.52 \\
\hline P5 & 6 & $63.52 \pm 0.22$ & 381.12 & $8465 \pm 0.01$ & 50790 & 133.27 & 2.85 & 2.49 \\
\hline P6 & 6 & ND & ND & ND & ND & ND & ND & ND \\
\hline P7 & 6 & ND & ND & ND & ND & ND & ND & ND \\
\hline
\end{tabular}

$\mathrm{ND}=$ not detected; $\mathrm{CE}=$ crude enzyme; $\mathrm{F} 1=$ fraction $70 \% ; \mathrm{F} 2=$ fraction $2=$ residual filrate; $\mathrm{Dt}=$ dialysate; $\mathrm{P} 1=$ dialysate product; $\mathrm{P} 2=$ enzyme with buffer; P3 = elution with $\mathrm{NaCl} 0.05 \mathrm{M}$; P4 = elution with $\mathrm{NaCl} 0.1 \mathrm{M}$; P5 = elution with $\mathrm{NaCl} 0.2 \mathrm{M}$; P6 = washed resin with $\mathrm{NaCl}$; 7 = washed resin with buffer. All values are reported as mean $\pm \mathrm{SD}$ (Standard deviation), $\mathrm{n}=3$ measurements 


\section{Characterization of cellulase}

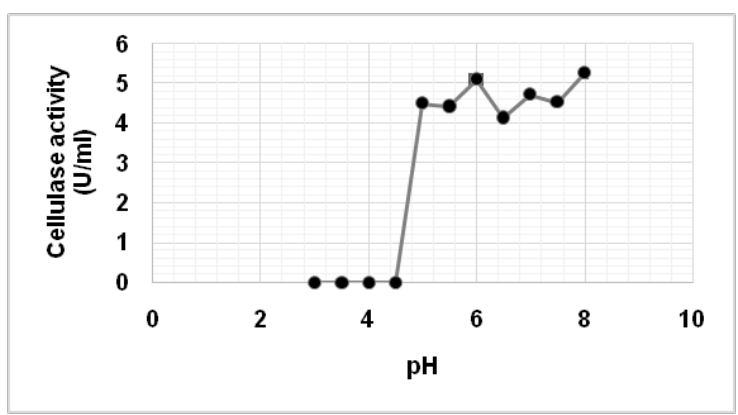

Fig. 4: Effect of $\mathrm{pH}$ on the activities of cellulases of $C$. globosum, all values are reported as mean $\pm S D$ (Standard deviation), $n=3$ measurements

The effect of $\mathrm{pH}$ on cellulase activity was determined in different buffers with $\mathrm{pH}$ values ranges from 3 to 8 (fig. 4). Activities of the enzymes were found to be greatly affected by $\mathrm{pH}$ changes. The enzyme exhibited high activity 3.5 and 6.0. The optimum enzyme activity was observed at 6.0. Fungal cellulases with $\mathrm{pH}$ values of 4.5 to 6.0 are common and have been obtained. From the results, it is noted that the enzymes are more active in the weak acid region than the alkaline region. The decrease in activities at the extremely acidic $\mathrm{pH}$ or at alkaline $\mathrm{pH}$ values might be due to the destruction of active site as well as changes in the secondary or tertiary structure of cellulase.

The activity of the enzyme was determined at various temperatures ranges from 30 to $60^{\circ} \mathrm{C}$ and the results can be seen in fig. 5. The activity of cellulase was increased gradually with the increase or decrease of temperature. The enzyme exhibited high activity at 45 to $55^{\circ} \mathrm{C}$ and maximum activity at $50^{\circ} \mathrm{C}$. Activity of cellulase was lost its activity at $60^{\circ} \mathrm{C}$ or above and as well as at $30^{\circ} \mathrm{C}$ or below $30^{\circ} \mathrm{C}$ $(40 \sim 60 \%)$. It is noted that this decrease in the activities of the enzyme at higher temperature might be due to the destruction of the secondary or tertiary structure of the enzyme.

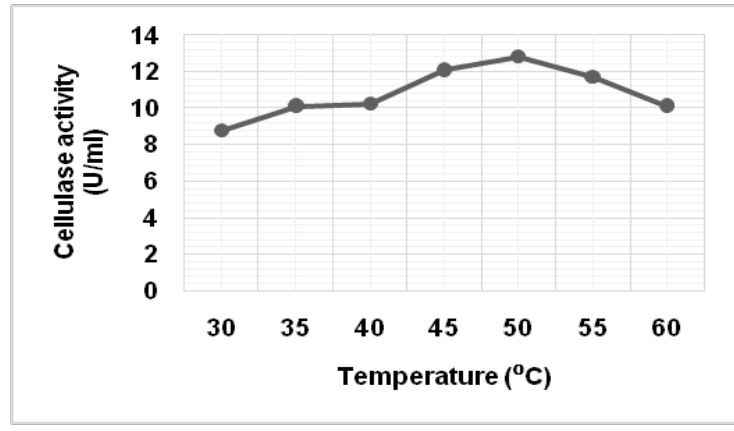

Fig. 5: Effect of temperature on the activities of cellulases of $C$ globosum, all values are reported as mean \pm SD (Standard deviation), $n=3$ measurements

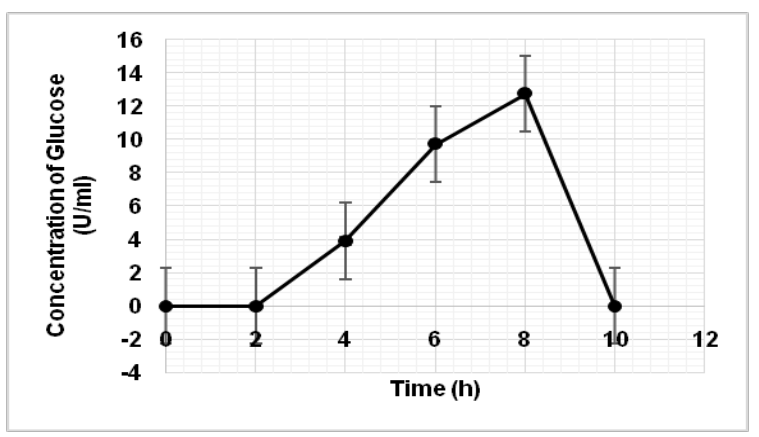

Fig. 6: Optimization duration of hydrolysis, all values are reported as mean $\pm \mathrm{SD}$ (Standard deviation), $\mathrm{n}=3$ measurements

Based on fig. 6, the lowest glucose concentration was found in the duration of hydrolysis for $2 \mathrm{~h}$ (with optimal $\mathrm{pH}$ and temperature). Therefore, the hydrolysis process will be carried out under these conditions so that the result of MCC has a large randemen.

Screening of clear zone-based cellulose activity in medium CMC

Table 2: Results of screening of cellulase enzyme activities based on clear zones in CMC media

\begin{tabular}{lll}
\hline Mold & Diameter of clear zone $(\mathbf{m m})$ & Diameter of the colony (mm) \\
\hline TR & $50,00 \pm 1,00$ & $6.00 \pm 0.00$ \\
CG & $45.00 \pm 2.00$ & $6.00 \pm 0.00$ \\
PN & $36.33 \pm 0.57$ & $6.00 \pm 0.00$ \\
\hline
\end{tabular}

$\mathrm{TR}=$ Trichoderma reesei, $\mathrm{CG}=$ Chaetomium globosum, $\mathrm{PN}=$ Paecilomyes niveus, all values are reported as mean $\pm \mathrm{SD}$ (Standard deviation), $\mathrm{n}=3$ measurements

The results from measurements of clear zone, the crude enzyme of Chaetomium globosum showed a clear zone diameter of $45 \mathrm{~mm}$ and cellulolytic index 6.5, Trichoderma reesei showed a clear zone diameter of $50 \mathrm{~mm}$ and cellulolytic index 7.3 which means that Chaetomium globosum has almost the same as Trichoderma reesei that has high cellulase enzyme activity.

\section{Quantitative test (DNS method)}

The process of making a standard glucose solution using several serial concentrations, namely 60 ppm, 75 ppm, 90 ppm, 105 ppm,

\section{Preparation and characterization of MCC by enzymatic hydrolysis}

$120 \mathrm{ppm}, 135 \mathrm{ppm}, 150 \mathrm{ppm}$, and $165 \mathrm{ppm}$ to obtain linear regression equations and calibration curves. The linear regression equation ( $\left.\mathrm{y}=0,0099 \mathrm{x}-0,4091 ; \mathrm{R}^{2}=0,9941\right)$ was then used to calculate glucose concentration and cellulase enzyme activity in the sample.

MCC was prepared by inserting an erlenmeyer that contains cellulose, buffer and purified enzyme in an incubator shaker set at $50{ }^{\circ} \mathrm{C}$ with a speed of $125 \mathrm{rpm}$ for $2 \mathrm{~h}$ (according to the temperature, $\mathrm{pH}$ and optimal hydrolysis time). Then, the obtained of MCC was identified and characterized as below.

Table 3: Results of the yield of MCC

\begin{tabular}{lll}
\hline Mold & Weight & Yield \\
\hline TR & 8.75 & $87,5 \%$ \\
CG & 9.5 & $95 \%$ \\
\hline
\end{tabular}



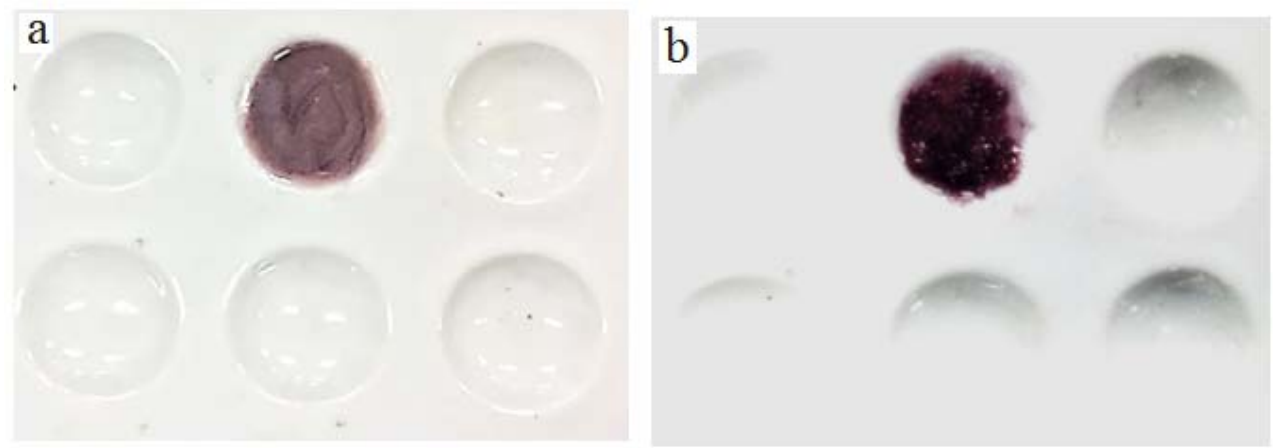

Fig. 7: Qualitative identification of samples using ZnCl (left: Avicel; right: sample), this identification resulted in violet purple on the reference (Avicel $\mathrm{PH}$ 101) and on the sample after $\mathrm{ZnCl}$ drops which proved that the sample contained cellulose.

FTIR

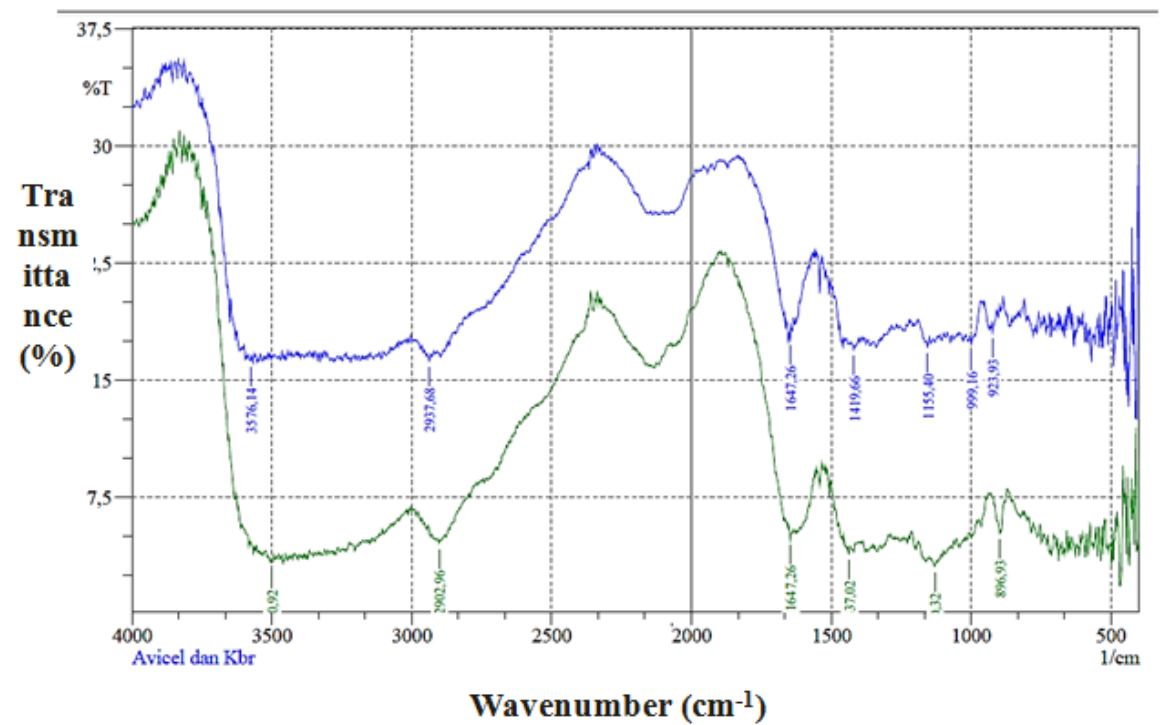

Fig. 8: Comparison of the results of Avicel PH-101 (blue) reference FTIR spectrum with the sample (green)

Although there were small differences between the reference and the sample, the FTIR spectrum showed a spectrum of common characteristics of MCC.

MCC that produced in this study was characterized using FTIR. Characterization was using FTIR aimed to determine the functional groups in the sample. Fig. 8 shows the FTIR spectrum generated from the sample. The FTIR spectrum of the sample shows peaks at wave numbers 3500.92, 2902.96, 1647.26, 1437.02, 1130.32, 1112.93 and 896.93. While the Avicel spectrum as a reference shows peaks at numbers 3576.14, 2937.68, 1647.26, 1419.66, 1155.4, 923.93. The peaks indicate the presence of $\mathrm{O}-\mathrm{H}, \mathrm{C}-\mathrm{H}, \mathrm{C}=\mathrm{O}, \mathrm{C}-\mathrm{O}-\mathrm{C}$, and $\mathrm{C}-\mathrm{O}$ stretching groups, and $\mathrm{CH} 2$ and $\mathrm{C}-\mathrm{H}$ bending.

There was the main peak of MCC in reference and sample, there was also a peak in the $1437.02 \mathrm{~cm}^{-1}$ region indicating the presence of clusters in $\mathrm{C}-\mathrm{OH}, \mathrm{CH}$, and clusters in the region of $1155.4 \mathrm{~cm}^{-1}$ at the reference and $1130.32 \mathrm{~cm}-1$ in the sample, indicating the presence of a cyclic monosaccharide group, $\mathrm{C}-\mathrm{C}$, or $\mathrm{C}-\mathrm{O}-\mathrm{C}$ of asymmetry, which belongs to the cellulose component. FTIR spectrum analysis showed that the result of MCC was a pure cellulose compound.

The FTIR spectrum showed a decrease in absorbance value at wavenumber 3500.92 and $2902.96 \mathrm{~cm}^{-1}$, which indicates a strong decrease in bonding in the $\mathrm{O}-\mathrm{H}$ and $\mathrm{C}-\mathrm{H}$ stretching groups which indicates more crystalline regions in MCC.

\section{Organoleptic test}

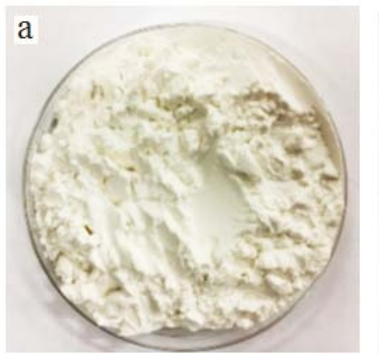

b

Fig. 9: The result of organoleptic on avicel PH-101 (a) and sample (b)

From the MCC produced and after comparison with the reference MCC, Avicel PH 101 (fig. 9) can be seen that the color produced from the sample is almost the same as Avicel, except that the grain is still rather rough and not as smooth as Avicel PH 101, but the difference is not too significant. 
Table 4: Results of particle analysis on the sample with particle size analysis (PSA)

\begin{tabular}{lllll}
\hline & dv10 $(\boldsymbol{\mu m})$ & dv50 $(\boldsymbol{\mu m})$ & dv90 $(\boldsymbol{\mu m})$ & Mean $(\boldsymbol{\mu m})$ \\
\hline Reference Avicel PH-101 & 6.25 & 15.61 & 24.00 & 15.56 \\
Sample & 16.78 & 105.87 & 31.92 & 143.59 \\
\hline
\end{tabular}

$\mathrm{dv}=$ diameter over volume, $\mathrm{n}=1$ measurement

X-Ray diffraction analysis of MCC
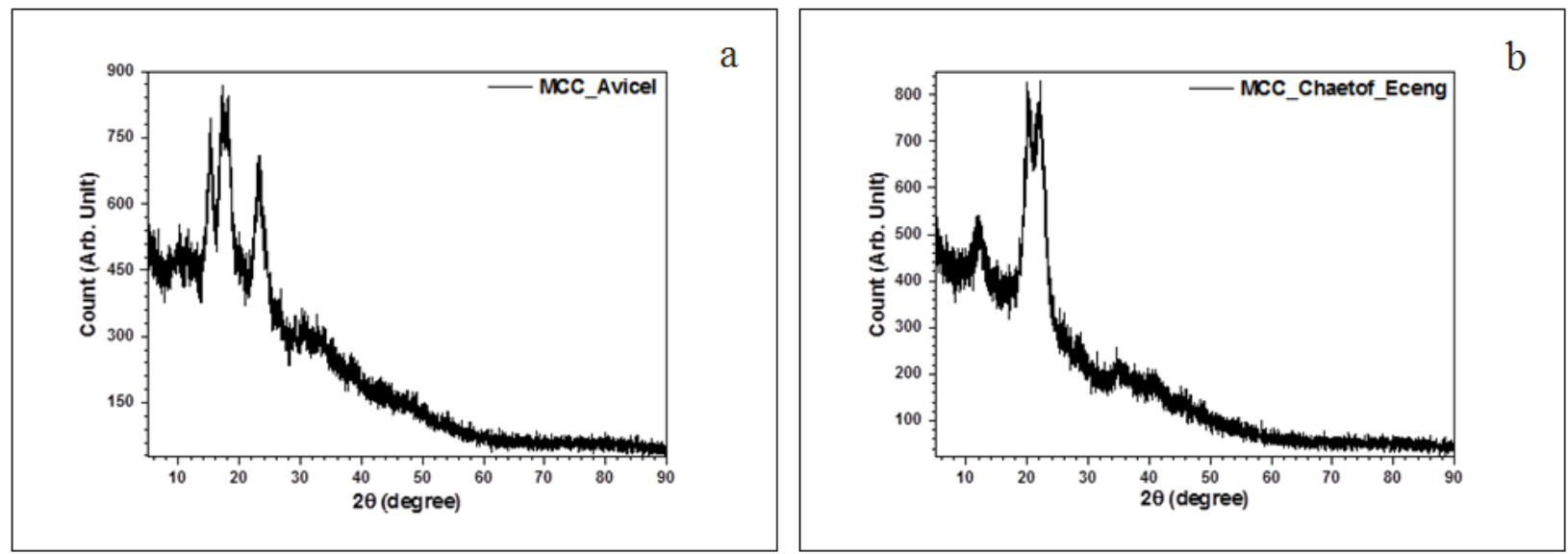

Fig. 10: Diffractogram of reference (a) and sample (b)

From the result of XRD analysis (fig. 10), the crystal and the amorphous of the sample is shown on the value of $2 \theta$ (deg). In the hydrolysis result of the sample, there are 2 peaks that indicated the existence of crystal character at 19,9984 with intensity 828 and 22.2043 with intensity 830 . For amorphous nature, there is 1 peak at $2 \theta(\mathrm{deg})$ value at 11.9927 with intensity 541 . The presence of 2 crystalline and amorphous peaks is influenced by the source of samples derived from water hyacinth and the manufacture of $\alpha$-cellulose using a strong base to remove lignin. Diffractogram from the sample is almost the same as Avicel, the difference is not too significant.

\section{DISCUSSION}

The results obtained from the preliminary process are then weighed and crushed to a fine powder. But in the process, it was found some difficulties that are difficult to clean the powder because of the original color of dark green dust. In addition to the washing process, this can occur due to a lack of perfection in the process of delignification. After being isolated the dried powder was very difficult to crush or blended, so The result of this powder was not smooth and the shape is elongated. So it must be washed repeatedly to get a powder with a $\mathrm{pH}$ of 7.0 (neutral), the washing water becomes clear and the color of powder was white bone (fig. 1).

Cellulase is an enzyme that can break down cellulose. Cellulase is an enzyme consist of 3 components: 1) Endoglucanase or known as 1,4a-D-glucan-4-glucanohydrolase, has functions to randomly hydrolyze the amorphous part of cellulose fibers to produce oligosaccharides of different lengths and new cellulose chain ends will be formed [19]; 2) Exoglucanase, including 1,4-a-D-glucan-4glucanohydrolase (or cellodextrinase) and 1,4-a-D-glucancellobiohydrolase (or cellobiohydrolase), breaks down cellulose from the reducing and non-reducing ends to produce cellobiose and/or glucose[20]; and 3) $\beta$-glucoside glucohydrolases better known as $\beta$-glucosidase. $\beta$-glucosidase is an enzyme used to hydrolyze cellobiose and in some cases can hydrolyze cellooligosaccharides to glucose[20].

In precipitation of ammonium sulfate, the process was carried out to make effective enzyme purification used the salting-out method assumed that at high salt concentrations (saturation) will increase the hydrophobic interaction between protein and water, where water will tend to be attracted by salt ions so that the solubility of the protein in water will decrease and protein deposition occurs. therefore these proteins will separate from each other depending on the different sizes of protein molecules contained in the solution.

The change in $\mathrm{pH}$ affects the functional group ionization which can cause enzyme confrontation and its catalytic properties which will affect the hydrogen bonds that contained in the enzyme. The change of enzyme confrontation can result in a decrease in enzyme activity caused by enzyme confrontation that is different from substrate confrontation.

The sample of cellulase that used was the supernatant of the crude enzyme from the isolate of the mold. The medium that used was CMC with lugol stained at the end after incubation. CMC (Carboxymethylcellulose) is a derivative of cellulose that can be used as a medium for testing the activity of cellulase. The addition of Lugol as a dye to make it easier and measure that the clear zone formed. Lugol reagent will be bound at 1.4- $\beta$ that will provide blueblack color of glycoside on cellulose. Meanwhile, the transparent color showed that cellulose has been decomposed into monosaccharides that can not form a complex with iodine of lugol reagent. The ability to form clear zone on a specific media indicates that the function is able to produce the cellulolytic enzyme, cellulase.

\section{CONCLUSION}

As the conclusion, among the isolates, Chaetomium globosum was considered as the best source of cellulase with suitable activity for preparation of MCC. The enzyme from Chaetomium globosum has a high activity of cellulase $(45 \mathrm{~mm})$ and higher yield of MCC than Trichoderma reesei $(87,5 \%)$. The optimum condition of enzymatic hydrolysis with cellulase with the substrate of water hyacinth was on the second hour when the glucose concentration is low. Based on the results of organoleptic, PSA and XRD, there was a similar characteristic of crystalline between MCC from hyacinth a-cellulose and reference Avicel PH 101.

\section{ACKNOWLEDGMENT}

We would like to thanks Directorate of Research and Engagement, Universitas Indonesia for research grant as financial support of our study. 


\section{AUTHORS CONTRIBUTIONS}

The entire authors have contributed equally

\section{CONFLICT OF INTERESTS}

This was a non-funding research work, that we declare there were no conflicts of interest

\section{REFERENCES}

1. Ahmed AF, Moahmed Naby. Pretreatment and enzymatic saccharification of water hyacinth cellulose. Carbohydrate Polymers 2012;87:2109-13.

2. Gaonkar SM, Kulkarni PR. Microcrystalline cellulose from water hyacinth. Act Polymer 1986;37:189-90.

3. Hindi SSZ. Microcrystalline cellulose: the inexhaustible treasure for the pharmaceutical industry. Nanosci Nanotech Res 2017;4:17.

4. Fuadi AM, Harismah K. Perbandingan efektifitas pembuatan glukosa dari kertas bekas secara hidrolisis Asam dan enzim. J Teknol Bahan Alam 2017;1:6-11.

5. Shobana P, Maheswari NU. Production of cellulase from Aspergillus fumigatus under submerged and solid-state fermentation using agricultural waste. Int J Adv In Pharm 2013;2:595.

6. Zhang YH, Himmel ME, Mielenz JR. Outlook for cellulase improvement: screening and selection strategies. Biotechnol Adv 2006;24:452-81.

7. Megha SV, Maragathavalli S, Brindha S, Karthikeyan V, Annadurai B, Gangwar SK. Isolation and purification of cellulase. Int J Sci Nat 2015;6:474.

8. Morana AM. Cellulase from fungi and Bacteria and their biotechnological applications. In: AE Golan. Cellulase: types and action, mechanism, and user. New York: Nova Science Publisher, Inc; 2011.
9. Gandjar I, Sjamsuridzal W, Oettari A. Mikologi dasar dan terapan. Jakarta: Yayasan Obor Indonesia; 2006.

10. Kazuhisa Miyamoto Renewade. Biological system for alternative sustainable energy production (FAO-Agricultural Services Bulletin, 128), Osaka University, Osaka, Japan; 1997. p. 451-6.

11. Suryadi H, Sutriyo, Sari HR, Rosikhoh D. Preparation of microcrystalline cellulose from water hyacinth powder by enzymatic hydrolysis using cellulase of the local isolate. J Young Pharm 2017;9:19-23.

12. Fagbohunka BS, Okonji RE, Adenike AZ. Purification and characterization of cellulase from Termite Ametermes eveuncifer (Silverstri) soldiers. Int J Bio 2016;9:2-7.

13. Ardhiyana R. Kapang pelapuk putih Trametes versicolor untuk proses biodelignifikasi limbah tanaman jagung. IPB; 2011.

14. Begum MF, Absar N. Purification and characterization of intracellular cellulase from Aspergillus oryzae ITCC-4857.01 Kor Soc Myc 2009;37:121-7.

15. Hasanah N, Saskiawan I. Aktivitas selulase isolat jamur dari limbah media tanam jamur merang. Pros Sem Nas Masy Biodiv Indon 2015;1:1110-5.

16. United States Pharmacopoeial Convention. The United States Pharmacopeia, USP 30/The National Formulary, NF 25. Rockville, MD: U. S. Pharmacopeial Convention. Inc; 2007. p. 2635.

17. Harmita. Analisis Fisiko Kimia. Depok: Departemen Farmasi FMIPA Universitas Indonesia; 2006.

18. British Pharmacopoeia Commission. British Pharmacopoeia. London: Stationery Office; 2008.

19. Howard R, Abotsi E, Jansen V, Howard S. Lignocellulose biotechnology: issues of bioconversion and enzyme production Afr J Biotech 2003;2:602-19.

20. Lynd LR, Weimer PJ, Van ZWH, Pretorius IS. Microbial cellulose utilization: fundamentals and biotechnology. Microbiol Mol Biol 2002;66:506-77. 